\title{
Thymoquinone induces apoptosis and DNA damage in 5-Fluorouracil-resistant colorectal cancer stem/progenitor cells
}

\author{
Farah Ballout ${ }^{1}$, Alissar Monzer ${ }^{1}$, Maamoun Fatfat ${ }^{1}$, Hala El Ouweini ${ }^{1}$, Miran A. \\ Jaffa $^{2}$, Rana Abdel-Samad ${ }^{3}$, Nadine Darwiche ${ }^{3}$, Wassim Abou-Kheir ${ }^{4}$ and Hala \\ Gali-Muhtasib ${ }^{1,4}$ \\ ${ }^{1}$ Department of Biology, American University of Beirut, Lebanon \\ ${ }^{2}$ Department of Epidemiology and Population Health, American University of Beirut, Lebanon \\ ${ }^{3}$ Department of Biochemistry and Molecular Genetics, American University of Beirut, Lebanon \\ ${ }^{4}$ Center for Drug Discovery and Department of Anatomy, Cell Biology and Physiological Sciences, American University of \\ Beirut, Lebanon \\ Correspondence to: Hala Gali-Muhtasib, email: amro@aub.edu.lb \\ Wassim Abou-Kheir, email: wa12@aub.edu.lb \\ Keywords: thymoquinone; colorectal cancer stem cells; 5-Fluorouracil resistance; colonospheres; apoptosis \\ Received: October 08, $2019 \quad$ Accepted: December 16, $2019 \quad$ Published: August 04, 2020
}

Copyright: Ballout et al. This is an open-access article distributed under the terms of the Creative Commons Attribution License 3.0 (CC BY 3.0 ), which permits unrestricted use, distribution, and reproduction in any medium, provided the original author and source are credited.

\section{ABSTRACT}

The high recurrence rates of colorectal cancer have been associated with a small population of cancer stem cells (CSCs) that are resistant to the standard chemotherapeutic drug, 5-fluorouracil (5FU). Thymoquinone (TQ) has shown promising antitumor properties on numerous cancer systems both in vitro and in vivo; however, its effect on colorectal CSCs is poorly established. Here, we investigated TQ's potential to target CSCs in a three-dimensional (3D) sphere-formation assay enriched for a population of colorectal cancer stem/progenitor cells. Our results showed a significant decrease in self-renewal potential of CSC populations enriched from 5FUsensitive and resistant HCT116 cells at 10 -fold lower concentrations when compared to 2D monolayers. TQ decreased the expression levels of colorectal stem cell markers CD44 and Epithelial Cell Adhesion Molecule EpCAM and proliferation marker Ki67 in colonospheres derived from both cell lines and reduced cellular migration and invasion. Further investigation revealed that TQ treatment led to increased TUNEL positivity and a dramatic increase in the amount of the DNA damage marker gamma H2AX particularly in 5FU-resistant colonospheres, suggesting that the diminished sphere forming ability in TQ-treated colonospheres is due to induction of DNA damage and apoptotic cell death. The intraperitoneal injection of TQ in mice inhibited tumor growth of spheres derived from 5FU-sensitive and 5FU-resistant HCT116 cells. Furthermore, TQ induced apoptosis and inhibited NF-KB and MEK signaling in mouse tumors. Altogether, our findings document TQ's effect on colorectal cancer stem-like cells and provide insights into its underlying mechanism of action.

\section{INTRODUCTION}

Colorectal cancer (CRC) is the third most common cancer in both men and women and the third leading cause of cancer-related deaths in the United States [1]. However, most of the patients are diagnosed in late stages, and approximately $50 \%$ of them encounter metastatic progression [2]. For metastatic CRC, treatments typically include chemotherapy with conventional agents such as 5-fluorouracil (5FU). Since its discovery 50 years ago, $5 \mathrm{FU}$ has been the backbone of treatments for CRC, but with a reduced success rate of less than 30\% [3]. The ineffectiveness of $5 \mathrm{FU}$ has been mainly limited by drug resistance [4, 5]. Most of the colorectal cancer-associated mortality stems from the recurrence and metastatic spread of chemoresistant cells to other vital organs, mainly the liver and lungs [6]. A complete understanding of all the players remains to be uncovered; however, the presence 
of chemotherapy-resistant cancer stem cells (CSCs) is one of the significant causes of tumor recurrence [7]. CSCs can self-renew [8] and are known to be resistant to chemotherapies such as 5FU or oxaliplatin [9]. Therefore, there is a need to develop practical therapeutic approaches that target CSCs and prevent relapse [10, 11].

In the development and discovery of new potential anticancer agents, growing interest is heading towards 'safe' and widely available molecules, prominently from plant extracts. Thymoquinone (TQ: 2-isopropyl-5-methylbenzo1,4-quinone) is the primary active molecule of black seed essential oil, which has shown promising effects against cancer both in vitro and in vivo [12]. The ability of TQ to target nine of the ten hallmarks of cancer as well as its efficacy, selectivity against colorectal cancer and lack of toxicity to normal tissues makes it potentially interesting for colorectal cancer therapy [13]. TQ's ability to inhibit colorectal cancer growth and invasion and induce cell cycle arrest and apoptosis in colorectal cancer cell culture and animal models have been documented by us and others [13-17]. TQ has been shown to inactivate the JAK/STAT signaling pathway by inhibiting STAT3 phosphorylation, reducing c-Src and JAK2 activity and attenuating the expression of STAT3 target gene products [18]. TQ is known to modulate Wnt signaling through GSK-3 $\beta$ activation, $\beta$-catenin translocation, and reduction of nuclear c-myc [19]. TQ was also found to activate p53, induce PARP cleavage, and reactive oxygen species production (reviewed in [20]). Comprehensive studies about TQ's potential effect on colorectal CSCs are lacking [21]. Despite the promising anticancer activity of TQ, the main limitation for its clinical translation lies in its hydrophobicity, poor bioavailability and capacity to bind to plasma proteins [22]. Very few studies investigated the pharmacokinetic and pharmacodynamic characteristics of TQ. One study showed that TQ is reduced into hydroquinone by catalyzing liver enzymes [23] and was detected in the plasma of rats for up to $12 \mathrm{hrs}$ post oral administration [24]. In rabbits, the absolute bioavailability of TQ upon oral administration was $58 \%$ with a lag time of 23 minutes, and 99\% of TQ was bound to plasma proteins [25]. Identifying TQ binding targets in vivo and determining their distribution profile can greatly help in better understanding TQ's pharmacological properties.

In our study, we focused on investigating TQ's efficacy on human colorectal cancer HCT116 cells, which are sensitive and resistant to 5FU. The main aim was to study the effect of TQ on targeting the selfrenewal capacity of colorectal CSCs enriched from the parental and 5FU-resistant cell lines using the advanced three dimensional (3D) culture sphere-formation and propagation assay. In vitro and in vivo studies revealed the significant inhibitory potential of TQ on colorectal cancer cells with stem-like properties, which was found to be mainly mediated by induction of apoptosis. Our study documents TQ's promising effect on CRC cancer stemlike cells both in vitro and in vivo.

\section{RESULTS}

\section{TQ reduces the viability of $5 \mathrm{FU}$-sensitive and resistant HCT116 human colorectal cancer cell lines}

Our first objective was to investigate the in vitro effect of TQ on the growth of HCT116 5FU-sensitive and resistant colorectal cancer cell lines cultured in $2 \mathrm{D}$ monolayers. MTT results showed a precise time- and dose-dependent reduction in viability in response to TQ. In the 5FU-sensitive cell line, the $\mathrm{IC}_{50}$ of TQ at $48 \mathrm{hrs}$ and $72 \mathrm{hrs}$ was $\sim 40 \mu \mathrm{M}$ (Figure 1A). In 5FU-resistant cells, the inhibitory effect of TQ commenced at a concentration of $60 \mu \mathrm{M}$ at $48 \mathrm{hrs}$, decreasing cell viability by $40 \%$ (Figure $1 \mathrm{~A})$. The maximum percentage of reduction in viability at $72 \mathrm{hrs}$ in the sensitive cell line was $80-85 \%$ compared to $70-75 \%$ in the resistant cell line. These results were consistent with Trypan blue exclusion assay (Figure 1B) and with the changes in cell morphology and confluency following drug treatment in both cell lines. TQ's effect on normal cells has been previously reported where we showed that TQ was non-toxic to FHs74Int human normal intestinal cells for doses up to $60 \mu \mathrm{M}$ [26].

\section{TQ targets an enriched population of 5FU- sensitive and resistant human colorectal cancer stem-like cells}

Having established TQ's inhibitory effect on both cell lines in 2D, we focused on investigating its potential inhibitory effect on targeting self-renewal capacity of colorectal CSCs enriched from 5FU-sensitive and resistant cell lines in 3D cultures using sphere formation and propagation assays. Cells that were able to form spheres in the first generation (G1) were collected and propagated by dissociating spheres into single cells and re-seeding the same number of cells (2000 cells/well). The assay was performed until the fifth generation (G5). In the 5FU-sensitive cells, treatment with $3 \mu \mathrm{M}$ TQ significantly decreased the sphere formation ability up to G5 (Figure 2A). In the 5FU-resistant cells, on the other hand, most of the spheres treated with $3 \mu \mathrm{M} 5 \mathrm{FU}$ remained viable up until the fifth generation, which confirms resistance to 5FU (Figure 2B). Interestingly, successive propagation and treatment of 5FU-resistant cells with $5 \mu \mathrm{M}$ TQ significantly decreased sphere-forming unit (SFU) by a remarkable $70 \%$ after treatment (Figure $2 \mathrm{~B}$ ).

In addition to assessing the effect of TQ on selfrenewal capacity, we investigated its effects on sphere size. Spheres were propagated for several generations with or without treatment, and at each generation, sphere sizes were determined (Figure 2A and 2B). TQ had no significant effect on the size of spheres derived from both 5FU-sensitive and resistant cells where the average diameter was around $100 \mu \mathrm{m}$ with or without treatment. 
To further study TQ's effect on the enriched CSCs population, we analyzed the expression of the proliferation marker Ki67 and the stem cell markers CD44 and EpCAM. The immunofluorescent analysis showed that TQ treatment significantly decreased CD44 and Ki67 expression in 5FU-sensitive and 5FU-resistant HCT116 spheres by 1 to 2-fold (Figure 2D and 2E). Unlike 2D results (Figure 1C), immunohistochemical staining of spheres derived from both cell lines showed a significant reduction of EpCAM expression by $\sim 1$-fold (Figure 2C). This suggests that the reduction in sphere-forming ability is associated with decreased cellular proliferation and inhibition of key stem cell markers. Interestingly, TQ upregulated cytokeratin epithelial markers, CK8 and CK19, in 5FU-resistant spheres and maintained an elevated expression of both in 5FU-sensitive spheres (Figure $2 \mathrm{~F}$ ), which could be indicative of reduced potential of epithelial-to-mesenchymal transition.

\section{TQ reduces invasion and migration ability of 5FU-sensitive and resistant-HCT116 colorectal cancer cells}

To study the possible mechanism of inhibition of stemness observed by the substantial reduction in colonosphere formation, we investigated the effect of TQ on cell migration and invasion, two phenotypes that are associated with the progression to metastasis. TQ treatment decreased cell invasion, whereby the invasion ability of cells in response to FBS was significantly reduced by more than 3-fold compared to the control (Figure 3A). Also, TQ significantly inhibited cell migration ability of 5FU-sensitive ( $\sim 3$-fold) and resistant HCT116 cells ( $\sim 200$ fold) compared to the control at $48 \mathrm{hrs}$ (Figure 3B). This reduction in cell migration and invasion in response to TQ correlated with a significant downregulation in vimentin expression (1.5 to 2-fold decrease), an intermediate filament protein that is expressed in mesenchymal cells, and upregulation in $\mathrm{E}$ cadherin $(\sim 1.5$-fold $)$, an epithelial marker, in both 5FU-sensitive and resistant cells (Figure 3C). In addition, TQ up-regulated CK8 in 5FU-resistant cells when compared to control and maintained an elevated expression of both CK8 and CK19 in sensitive and resistant cells (Figure 1C). Collectively, these results suggest that TQ has a high inhibitory effect on colorectal cancer cell migration and invasion.

\section{TQ induces apoptosis and DNA damage in colorectal cancer stem/progenitor cells}

As mentioned previously, TQ caused a significant reduction in sphere number but not size, suggesting the
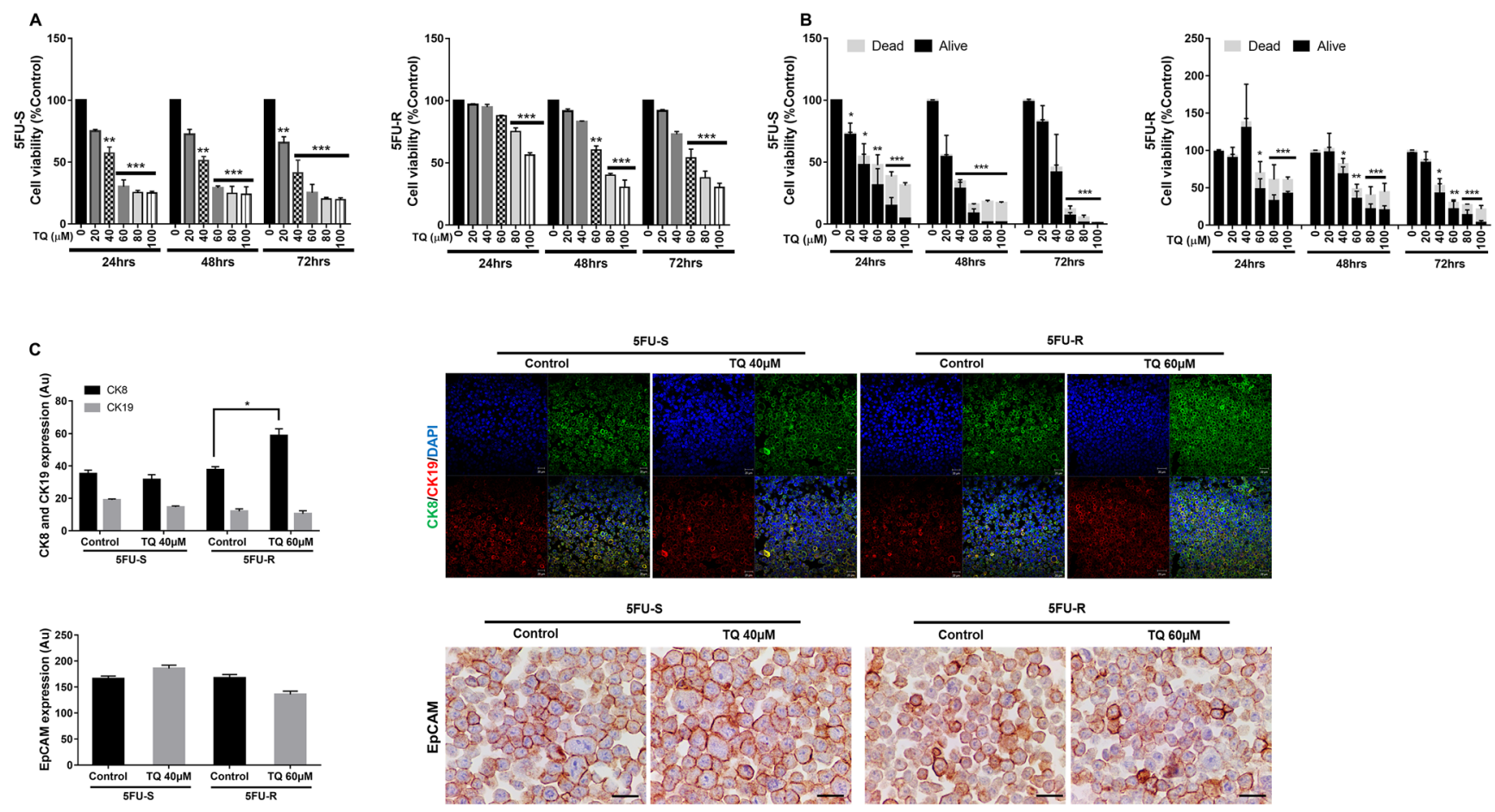

Figure 1: TQ reduces viability of 5FU-sensitive and 5FU-resistant HCT116 colorectal cancer cells. After incubation of 5FU-S and 5FU-R HCT116 colorectal cancer cells for 24, 48 and 72hrs with or without TQ, cell viability was determined using MTT assay (A) and Trypan blue dye exclusion assay (B). Results are expressed as percentage of the studied group compared to its control. Data represent an average of three independent experiments. The data are reported as mean $\pm \mathrm{SD}$ for MTT and mean \pm SEM for Trypan blue assay $\left({ }^{*} P<0.05 ;{ }^{* *} P<0.01 ;{ }^{* * *} P<0.001\right)$. (C) 5FU-S and 5FU-R HCT116 colorectal cancer cells treated or not with 40 and $60 \mu \mathrm{M}$ TQ respectively were immunofluorescently stained for CK8 and CK19 and immunohistochemically stained for EpCAM. Quantification and representative images are shown. Scale bar for immunofluorescent images is $20 \mu \mathrm{m}$ and for immunohistochemistry is $100 \mu \mathrm{m}$. 
involvement of a cell death mechanism. To determine TQ's mechanism of action, we performed TUNEL staining on 5FU-sensitive and resistant HCT116 G1 and G5 spheres (Figure 4A). TQ treatment led to increased TUNEL positivity, indicating that the diminished sphere forming ability in TQ-treated colonospheres was in part due to the induction of apoptosis. In the TQ-treated spheres, mean apoptotic index estimated by TUNEL was $11.3 \%$ and $11.8 \%$ as compared to $8 \%$ and $5.5 \%$ in control G1 and G5 5FU-sensitive spheres, respectively. In 5FU-resistant spheres, mean apoptotic index estimated by TUNEL was $8 \%$ and $14 \%$ in TQ-treated spheres as compared to $0.5 \%$ and $5.6 \%$ in control G1 and G5 spheres, respectively. Analysis of p53 protein expression in 5FU-sensitive and 5FU-resistant 2D cells and 3D spheres during TQ treatment showed up-regulation further confirming apoptosis induction (Figure 4C, 4D). This was also associated with an upregulation in p21 expression (Figure 4C, 4D). Western blot analysis also showed a decrease in
NF- $\kappa \mathrm{B}, \mathrm{PCNA}$ and $\mathrm{p}-\mathrm{MEK}$ expression especially in 3D colonospheres (Figure 4D).

An early cellular response to double-strand breaks is the phosphorylation at Ser139 of a subclass of eukaryotic histones, H2AX. To study TQ's effect on inducing DNA damage, we studied the expression of $\mathrm{H} 2 \mathrm{AX}$. Interestingly, TQ caused a dramatic increase in the amount of H2AX protein mainly in 5FU-resistant cells and spheres (Figure 4B, 4C) indicating a role of DNA damage pathway in these cells in response to TQ.

\section{TQ inhibits tumor growth in mice injected with 5FU-sensitive and resistant HCT116 spheres}

To experimentally prove that the HCT116 population derived from spheres is enriched with cells having stem-like properties, we assessed their tumorigenic potential in mice. NOD-SCID mice were used for the 5FU-sensitive cell line as they easily showed tumor
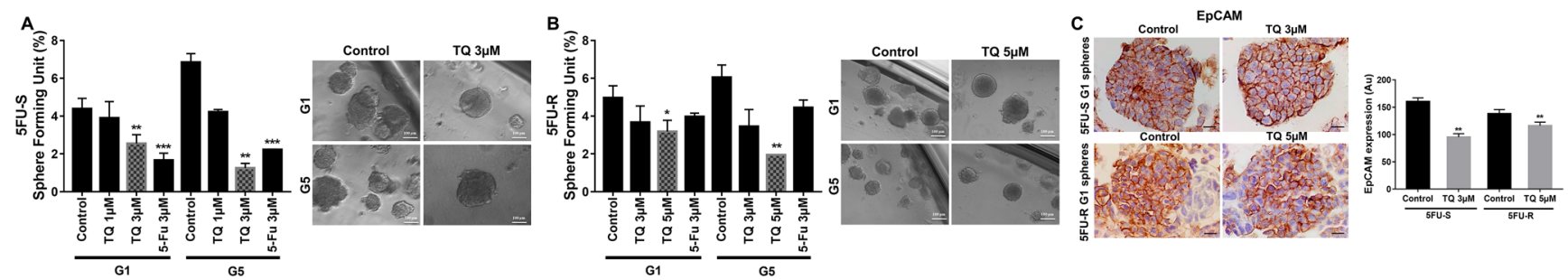

D
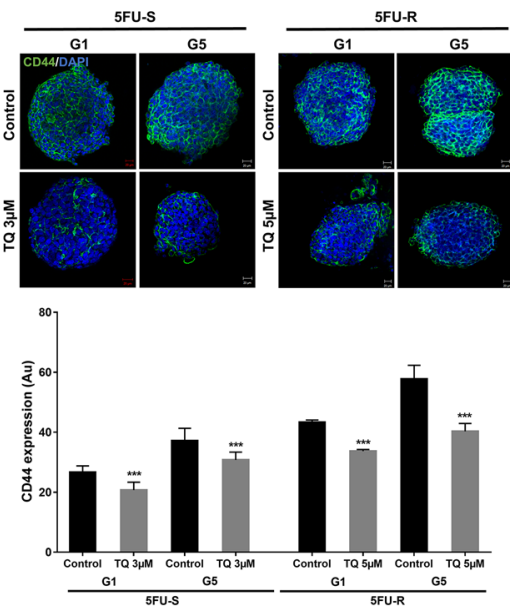
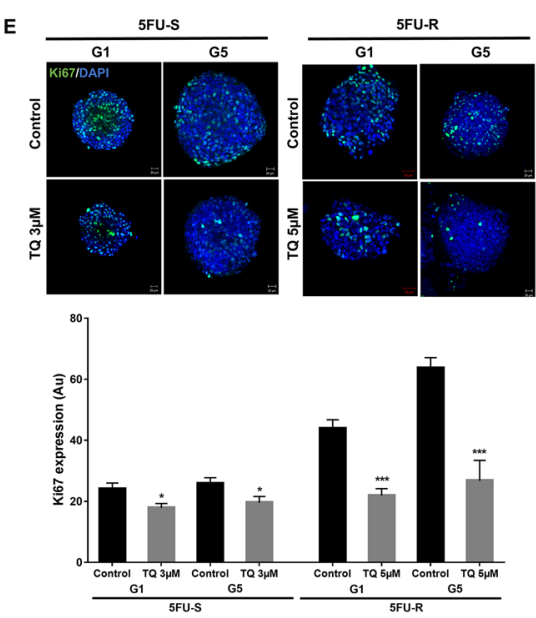
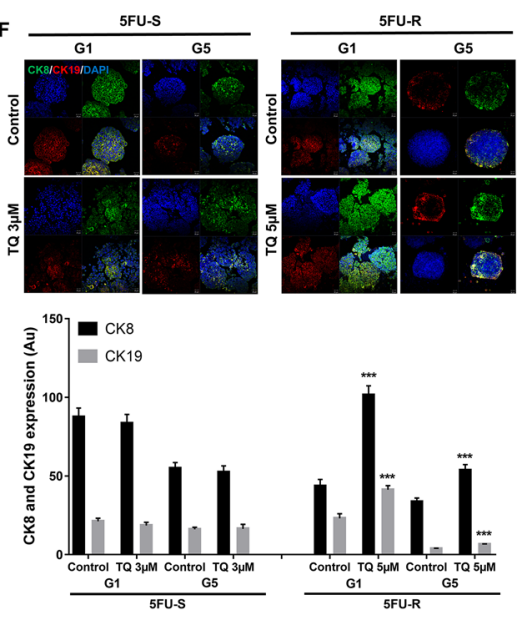

Figure 2: TQ reduces sphere-forming and self-renewal ability of colon cancer stem/progenitor cells. (A, B) Sphere forming unit (SFU) obtained from serially passaged colonopheres over five generations is shown under untreated conditions, TQ-treated $(1,3$ and $5 \mu \mathrm{M})$ and $5 \mathrm{FU}$-treated $(3 \mu \mathrm{M})$ condition for 5FU-S (A) and 5FU-R (B) HCT116 derived spheres. SFU is calculated according to the following formula: $\mathrm{SFU}=$ (number of spheres counted $\div$ number of input cells)*100. Colon CSCs were enriched from $5 \mathrm{FU}-\mathrm{S}$ and $5 \mathrm{FU}-$ R HCT116 cell line and treated with either TQ $(1,3$ and $5 \mu \mathrm{M})$ or media (control). Generated spheres are referred to as G1 (Generation 1) spheres. After each propagation, cells that were initially treated with TQ, 5FU or media (control) were seeded into separate wells. Spheres were propagated for five generations in duplicates for each condition. Data represent an average of three independent experiments and are reported as mean \pm SEM $\left({ }^{*} P<0.05 ;{ }^{* *} P<0.01 ;{ }^{* * *} P<0.001\right)$. Representative bright-field images showing the effect of TQ on SFU are shown next to the respective graphs. Images were visualized by Axiovert inverted microscope at $10 \times$ magnification and analyzed by Carl Zeiss Zen 2012 image software. Scale bar $100 \mu \mathrm{m}$. (C-F) Spheres were collected, fixed and stained for CD44, Ki67, CK8 and CK19 and EpCAM. Representative images were obtained using confocal and light microscopy and quantification of the intensity of EpCAM (C), CD44 (D), Ki67 (E) and CK8 and CK19 (F) stain in control and TQ treated 5FU-S and 5FU-R HCT116 G1 and G5 spheres was performed using Carl Zeiss Zen 2012 image software and ImageJ software for EpCAM intensity. Stain intensity was normalized to size. Data represent an average of three independent experiments and are reported as mean $\pm \operatorname{SEM}\left({ }^{*} P<0.05 ;{ }^{* *} P<0.01 ;{ }^{* * *} P<0.001\right)$. Scale bar $20 \mu \mathrm{m}$. 
development. 5FU-resistant cells failed to develop tumors in NOD-SCID mice, so NOD/Shi-scid IL2rgamma ${ }^{\text {null }}$ (NOG) mice were used. The number of spheres needed for tumor development was optimized by serial dilution. 100 5FU-sensitive and 250 5FU-resistant spheres induced tumor development in 4 and 8 weeks in NOD-SCID and NOG mice, respectively (data not shown). We have previously reported that intraperitoneal injections of TQ at doses up to $20 \mathrm{mg} / \mathrm{kg}$ are not toxic to mice and significantly delay tumor growth in a xenograft model of 5FU-sensitive HCT116 colorectal cancer [27].

To test the effect of TQ on targeting an enriched population of cells with stem-like properties in vivo, we injected two groups of NOD-SCID mice with 100 spheres derived from HCT116 sensitive cell line and two groups of NOG mice with 250 spheres derived from HCT116- resistant cell line. One group acted as a control, and the other group was treated with TQ at a dose of $20 \mathrm{mg} / \mathrm{kg}$ body weight [27] three times per week for 21 days by intraperitoneal injections when a palpable tumor was observed. TQ significantly inhibited tumor growth in these mice when compared to control group (Figure 5A, 5B). At the end of the treatment period, the average tumor volume was $1182 \mathrm{~mm}^{3}$ and $485 \mathrm{~mm}^{3}$ in the control group, while it was $79 \mathrm{~mm}^{3}(P<0.01)$ and 14
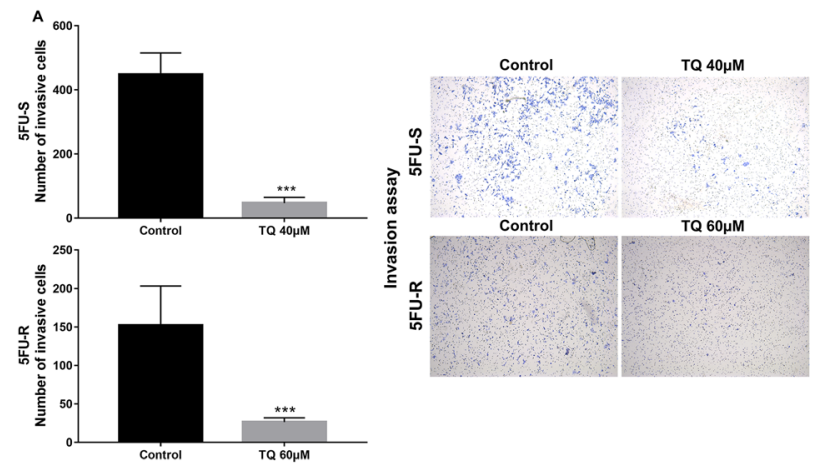

$\mathrm{mm}^{3}(P<0.001)$ in TQ treated mice injected with 5FUsensitive and 5FU-resistant spheres, respectively (Figure $5 \mathrm{~A}, 5 \mathrm{~B}$ ). A dose of $20 \mathrm{mg} / \mathrm{kg}$ TQ did not affect the body weight or resulted in animal death (data not shown), indicating that this dose is not toxic. Interestingly, two weeks after stopping TQ treatment, the average tumor volume in the TQ treated group $\left(558 \mathrm{~mm}^{3}\right.$ in 5FU-sensitive and $37.5 \mathrm{~mm}^{3}$ in 5FU-resistant) was still significantly lower than that of the control group (1451 $\mathrm{mm}^{3}$ in 5FU-sensitive and $459 \mathrm{~mm}^{3}$ in 5FU-resistant) (Figure 5C, 5D).

The diminished tumor size in TQ-treated xenografts was in part due to the induction of cell death, as shown by increased TUNEL positivity (Figure 6B). In the TQ-treated group, average apoptotic index estimated by TUNEL was $51.6 \%$ and $20 \%$ as compared to $4.2 \%$ and $2 \%$ in vehicle controls in mice injected with 5FU-sensitive and 5FUresistant spheres, respectively. Similar to in vitro results, the stem cell marker CD44 was also decreased in mouse tumor tissues upon TQ treatment (Figure 6C). Western blot analysis showed upregulation of p53, p21, $\gamma-\mathrm{H} 2 \mathrm{AX}$ and the NF- $\kappa \mathrm{B}$ inhibitor I $\kappa \beta \alpha$, and downregulation of the proliferation markers PCNA, NF- $\mathrm{B}$ (p65), and p-MEK in tumor tissues of TQ-treated mice (Figure 6A), similar to in vitro $3 \mathrm{D}$ results.

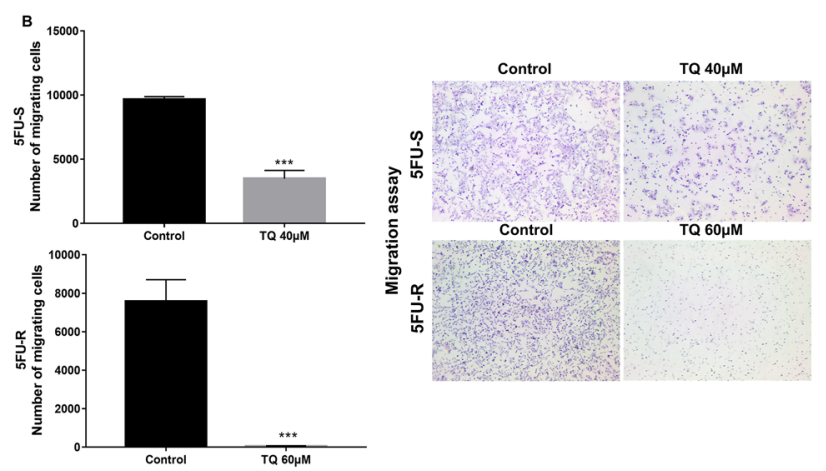

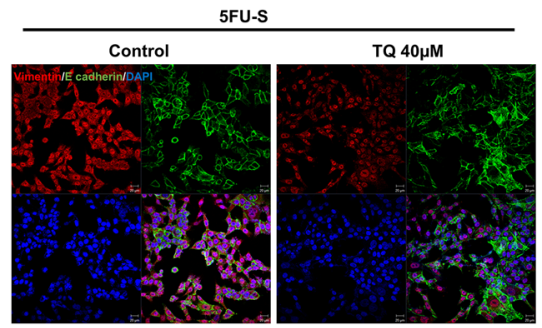
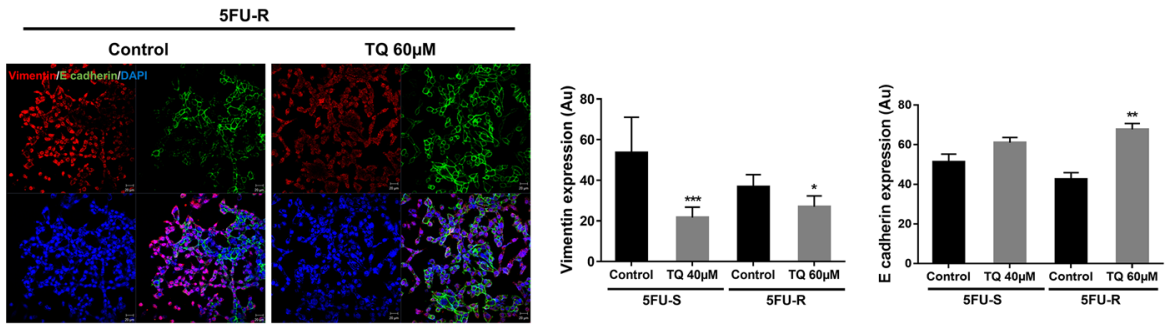

Figure 3: TQ reduces invasion and migration ability of 5FU-sensitive and 5FU-resistant $\mathrm{HCT} 116$ colorectal cancer cells. HCT116 cells were seeded onto the Matrigel-coated membrane (invasion assay) (A) or the uncoated membrane (migration assay) (B) in the top chamber of the transwell and were either treated or not with 40 and $60 \mu \mathrm{M}$ TQ respectively in the presence of FBS in the lower chamber. Cells that migrated/invaded to the lower chamber after $48 \mathrm{hr}$ were fixed with methanol, stained with $\mathrm{H} \& \mathrm{E}$, counted and represented as number of migrating/invading cells compared to the control. Data represent an average of three independent experiments. The data are reported as mean \pm SEM $\left({ }^{*} P<0.05 ;{ }^{* *} P<0.01 ;{ }^{* * *} P<0.001\right)$. (C) Representative confocal images and quantification of vimentin and E cadherin expression in 5FU-S and 5FU-R HCT116 colorectal cancer cells treated or not with 40 and $60 \mu \mathrm{M}$ TQ, respectively. Data represent an average of three independent experiments and are reported as mean $\pm \operatorname{SEM}\left({ }^{*} P<0.05 ;{ }^{* *} P<0.01 ;{ }^{* * *} P<0.001\right)$. Scale bar for immunofluorescent images $20 \mu \mathrm{m}$. 


\section{DISCUSSION}

The current study was designed to investigate the effect of TQ on targeting the self-renewal capacity of colorectal CSCs and its underlying mechanisms of action in 5FU-sensitive and resistant HCT116 cell lines in vitro and in xenograft mouse models. Sphere formation assay was used to enrich for colorectal CSCs as no consensus has been reached on the universal markers that define colorectal CSCs [28].

5FU remains to be the standard chemotherapy for metastatic CRC; however, cardiotoxicity and drug resistance limit its effectiveness. Various factors contribute to $5 \mathrm{FU}$ resistance which include a) genetic and epigenetic modifications within the cell itself, b) cell cycle and signaling pathway perturbations, c) or decreased drug delivery to cancer cells either by increased efflux out of the cell, decreased uptake or change in enzymes involved in metabolism [29]. Recent studies have also attributed colorectal cancer $5 \mathrm{FU}$ resistance to a population of cells with stem-like properties referred to as colorectal CSCs. Like other conventional cytotoxic chemotherapies, 5FU targets the rapidly dividing cells while sparing the quiescent or slowly cycling CSCs, thus enriching for the rare subsets of colorectal CSCs [30]. Therefore, identifying new therapeutic approaches that target CSCs is of high importance to prevent relapse. The natural compound TQ has shown promising antitumor activities against various cancer types [20]. In line with these studies, we have demonstrated that TQ exhibited anti-neoplastic effects by reducing the viability of 5FUsensitive and resistant HCT116 cell lines in a time- and dose-dependent manner and decreased the expression of the proliferation marker Ki67.

Many studies have reported the promising potential of co-administering TQ with traditional chemotherapeutic agents. $\mathrm{TQ} / 5 \mathrm{FU}$ combination has been shown to enhance 5FU action and to chemosensitize cancer cells to $5 \mathrm{FU}$ induced cell death in early stages of colorectal carcinogenesis in rats and in gastric cancer cells [31, 32]. However, studies tackling TQ's effect on CSCs are limited. Ndreshkjana et al. (2018) have recently reported that the combination of $5 \mathrm{FU}$ and TQ and their hybridization through esterification (SARB hybrid) targets stem cell gene signature in colorectal cancer cells [21]. Here we showed that TQ exhibits a strong inhibitory effect on the self-renewal potential of CSC populations enriched from 5FU-sensitive and resistant HCT116
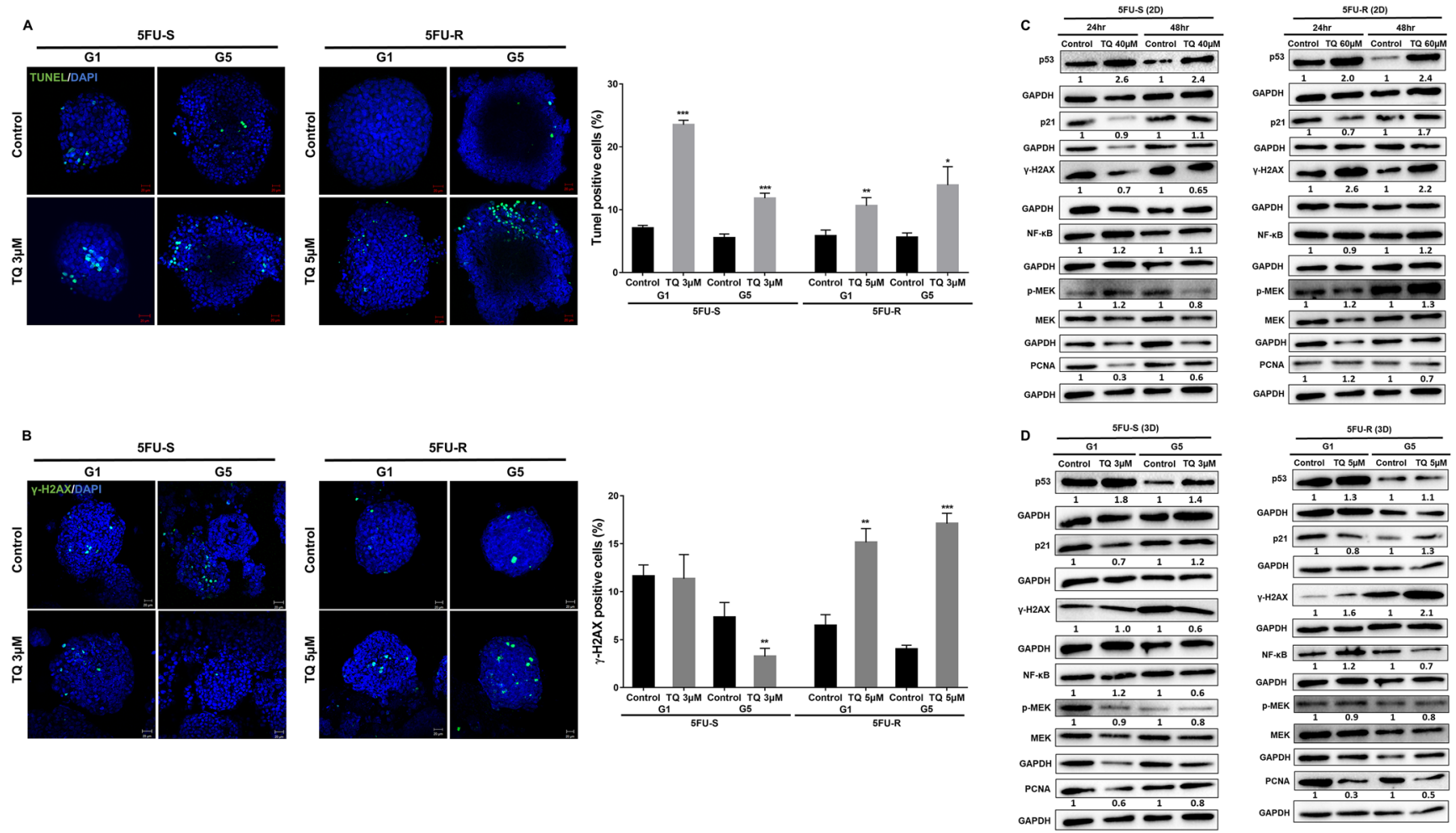

Figure 4: TQ induces apoptosis and DNA damage in colon cancer stem/progenitor cells. (A) Representative images of control and TQ treated 5FU-S and 5FU-R HCT116 G1 and G5 spheres after TUNEL staining. Scale bar $20 \mu \mathrm{m}$. TUNEL positive cells were counted and represented as mean percentage $\pm \mathrm{SD}\left({ }^{*} P<0.05 ;{ }^{* *} P<0.01 ;{ }^{* * *} P<0.001\right.$ significantly different from control. (B) Representative images of $\gamma-\mathrm{H} 2 \mathrm{AX}$ staining in control and TQ-treated 5FU-S and 5FU-R HCT116 G1 and G5 spheres. Scale bar $20 \mu \mathrm{m} . \gamma$-H2AX positive cells were counted and are represented as mean percentage \pm SEM $\left({ }^{*} P<0.05 ;{ }^{* *} P<0.01 ;{ }^{* * *} P<0.001\right.$ significantly different from control). (C, D) Analysis of p53, p21, $\gamma-\mathrm{H} 2 \mathrm{AX}, \mathrm{NF}-\mathrm{\kappa B}$ (p65), p-MEK and PCNA protein expression in 5FU-S and 5FU-R HCT116 cells and spheres during TQ treatment. Fold expression changes normalized to GAPDH and total MEK in case of p-MEK expression are given below the blots. 
cells demonstrating that CSCs, which are resistant to chemotherapy compared to the bulk of the tumor cells, are selectively and effectively targeted by TQ. This reduction in sphere-forming ability correlated with the observed decrease in the expression of the stem cell markers CD44 and EpCAM. It is important to note that CD44 expression was more prominent in 5FU-resistant cell line when compared to 5FU-sensitive suggesting its role in stemness and resistance. CD44 is a transmembrane glycoprotein highly expressed in almost every cancer cell and is crucial in tumor initiation and colonosphere propagation in vitro [33]. CD44 is known to have a multifunctional role in many cellular processes, like survival, growth, and differentiation, and may regulate stemness in CSCs [34]. Our results showed that TQ treatment significantly reduced CD44 expression in CSCs population enriched from 5FU-sensitive and resistant cells both in vitro and in vivo.

TQ has been shown to induce apoptosis by modulating several types of players including generation of reactive oxygen species [26], up-regulation of apoptotic mediators, interference with angiogenesis, metastasis and DNA damage markers [20, 35]. To understand the observed reduction in sphere-formation, we checked for apoptosis induction and activation of DNA damage markers in spheres derived from the two cell lines. TQ treatment led to increased TUNEL positivity and upregulation of p53 and p21, indicating that the diminished sphere-forming ability in TQ-treated colonospheres was due to the induction of apoptotic cell death. H2AX is a member of the histone H2A family and is one of the first molecules to be phosphorylated at serine $139(\gamma-\mathrm{H} 2 \mathrm{AX})$ in response to double-strand DNA breaks. This phosphorylation mediates the recruitment of repair factors to the damaged DNA sites [36]. H2AX has been proposed as a factor to assess response to treatment, and several agents and chemotherapeutic drugs used in colorectal cancer treatment have been shown to increase $\gamma$-H2AX, including oxaliplatin, sorafenib, valproic acid, and oncolytic adenovirus [37, 38]. The response to DNA damage results in either cell cycle arrest, to allow the lesions to be repaired, or in p53-dependent and independent apoptosis $[39,40]$. In this study, we showed that TQ downregulated $\gamma-\mathrm{H} 2 \mathrm{AX}$ in 5FU-sensitive cells, which could suggest that TQ has a low genotoxic potential in these cells since it induced p53 activation with minimal DNA damage response [41]. In addition, $\gamma$-H2AX plays an essential role in the process of DNA repair through the recruitment of DNA repair proteins such as 53BP1, RAD51, BRCA1, and MDC1 to the damage sites [42]. Therefore, this decrease in $\gamma-\mathrm{H} 2 \mathrm{AX}$ could indicate reduced DNA repair in malignant cells, which enhances their sensitivity to TQ. In contrast, $\gamma-\mathrm{H} 2 \mathrm{AX}$ was remarkably upregulated by TQ in 5FU-resistant cells, indicating activation of DNA damage response, which may generate a positive feedback loop that enhances p53 activity. DNA damage can cause various post-translational modifications on p53 that can enhance its ability to activate target
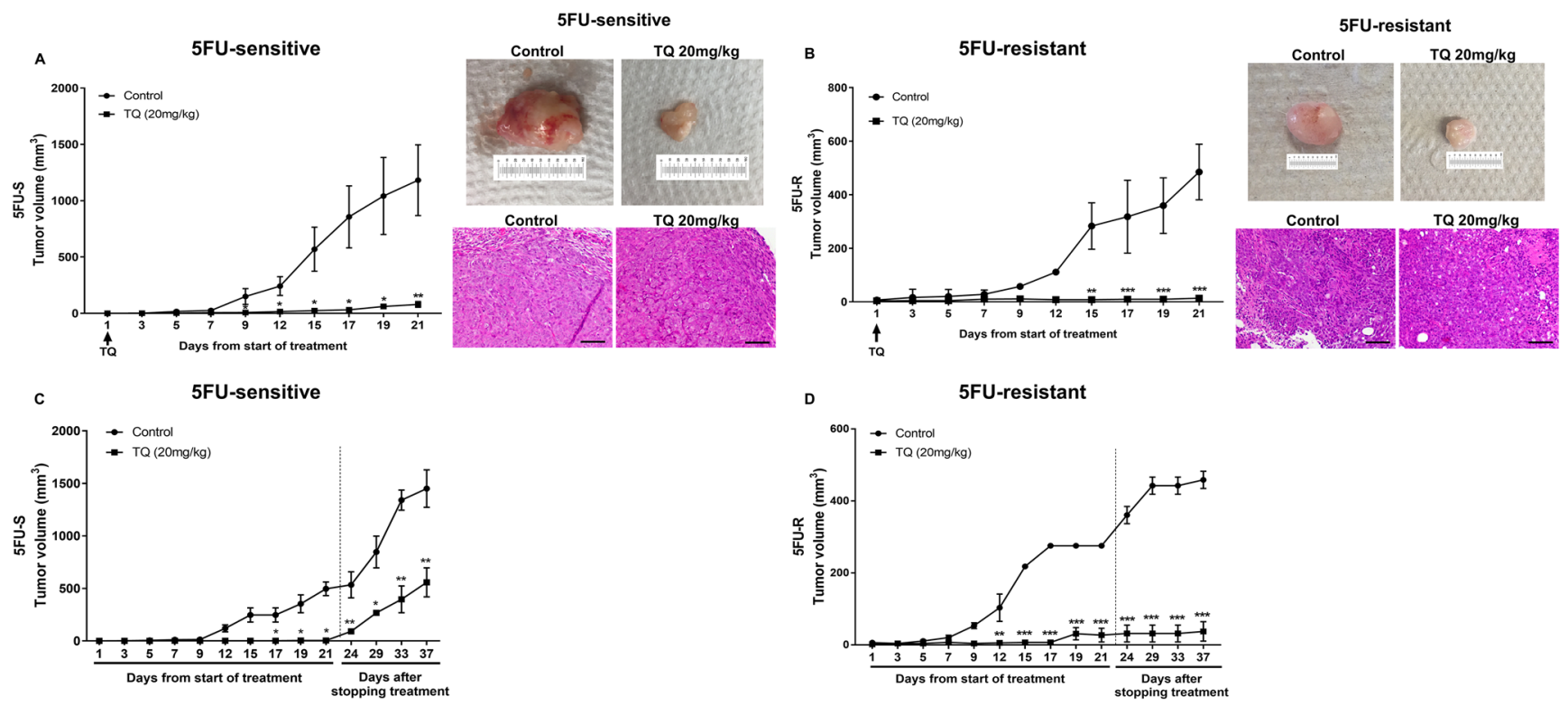

Figure 5: TQ reduces tumor growth in NOD-SCID and NOG mice. (A, B) NOD-SCID mice (8 mice/group) (A) were injected with 100 5FU-sensitive HCT116 G1 spheres and NOG mice (5 mice/group) (B) were injected with 2505 FU-resistant HCT116 G1 spheres and tumor progression was monitored. Tumor volume during 21 days of i. p. treatment (3×/week) with either $20 \mathrm{mg} / \mathrm{kg}$ TQ or $10 \%$ methanol in physiologic saline was reported. $P<0.05$ between TQ and vehicle (control) treated animals. Representative images of control and TQ-treated mice at day 21 and H\&E stain of tumor tissues are shown. (C, D) Average tumor volume of control and TQ treated mice ( $n$ $=3$ ) during and after stopping treatment for 2 weeks was monitored in NOD-SCID and NOG mice and showed an increase in volume that was still significantly different from control untreated group. 
genes and promote apoptosis [41] thus increasing the susceptibility of the chemo-resistant malignant cells to apoptosis by TQ. $\gamma$-H2AX was upregulated in both 5FU$\mathrm{S}$ and 5FU-R tumors, but this upregulation was more pronounced in 5FU-R tumors. Similar to in vitro results, p53 and p21 were also upregulated in these tumors suggesting apoptosis induction in response to TQ-induced DNA damage.

The ability of cancer cells to metastasize to vital organs is a major cause of cancer mortality [43]. TQ has been shown to inhibit migration and invasion of cancer cells by targeting epithelial to mesenchymal transition (EMT) markers Twist and E cadherin [44-46]. TQ was also shown to inhibit bone metastasis of breast cancer cells through abrogation of the CXCR4 signaling axis [12]. In accordance with these findings, our results also demonstrated that TQ significantly decreased the migration and invasion ability of 5FU-sensitive and resistant HCT116 cells, suggesting its role in inhibiting metastasis. CK8 and CK19 are members of the intermediate filament-forming proteins of epithelial cells. Several studies have provided evidence for active keratin involvement in cancer cell invasion and metastasis, as well as in treatment responsiveness [47]. Reduced expression of CK8 and CK20 has been associated with an increased transition in epithelial to mesenchymal cells in CRC [48,
49]. In this study, staining for CK8 and CK19 showed an increase in expression upon TQ treatment when compared to control mainly in the resistant cell line suggesting a protective role of TQ against metastasis.

To experimentally prove that the derived spheres are enriched with cells having stem-like properties, we injected a group of mice with HCT116 cells cultured in 2D monolayers and another group of mice with spheres. The validity of our model will be confirmed if the injected spheres show a higher tumor initiation capacity than 2D monolayer cells. Indeed, the injection of spheres derived from HCT116 sensitive cell line and not the 2D equivalent cell density into NOD-SCID immunocompromised mice resulted in tumor development, suggesting that spheres are rich in cells with stem-like properties. Treatment with 20 $\mathrm{mg} / \mathrm{kg}$ body weight of TQ was able to inhibit tumor growth in NOD-SCID mice injected with 5FU-sensitive spheres and NOG mice injected with 5FU-resistant spheres and tumor volume in TQ-treated group remained significantly lower than that of control after stopping treatment for two weeks, indicating a relatively potent inhibitory effect of TQ on tumor growth. Interestingly, TQ's effect on 5FUresistant induced tumor volume was irreversible when compared to 5FU-sensitive tumor volume after stopping treatment for two weeks suggesting a promising effect of TQ on the enriched population of chemoresistant colorectal
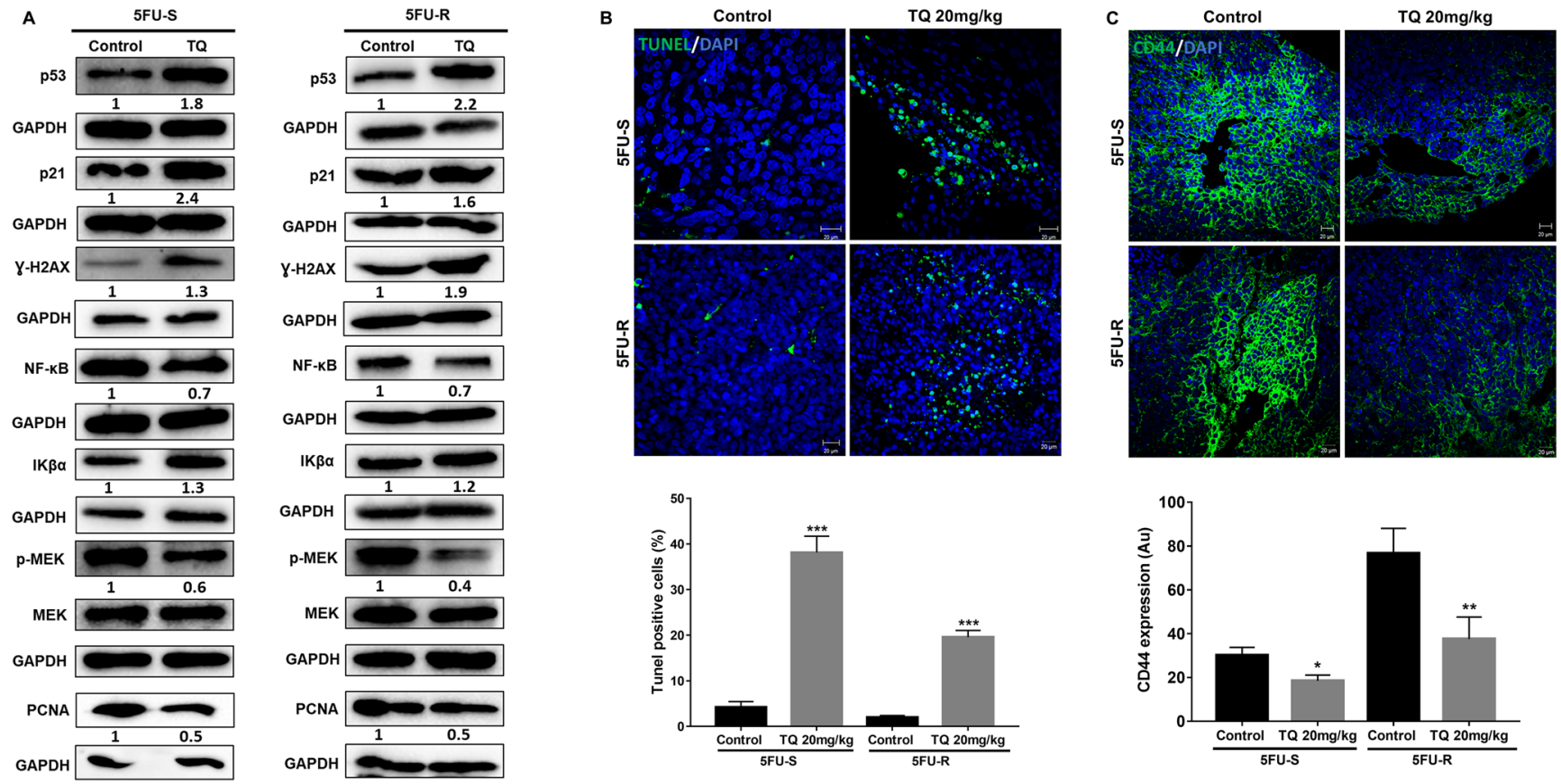

Figure 6: TQ induces apoptosis and reduces proliferation in NOD-SCID and NOG mice. (A) Analysis of p53, p21, $\gamma$-H2AX, NF- $\kappa \mathrm{B}$ (p65), I $\kappa \beta \alpha, \mathrm{p}-\mathrm{MEK}$ and PCNA protein expression in control and TQ-treated tissues from NOD-SCID and NOG mice injected with 100 5FU-S and 250 5FU-R HCT116 G1 spheres. Fold expression changes normalized to GAPDH and total MEK in case of p-MEK expression are given below the blots. (B) Representative images of control and TQ treated tissues from NOD-SCID mice injected with 100 5FU-S and 250 5FU-R HCT116 G1 spheres after TUNEL staining. Scale bar $20 \mu \mathrm{m}$. TUNEL positive cells were counted and are represented as mean percentage $\pm \operatorname{SEM}\left({ }^{*} P<0.05 ;{ }^{* *} P<0.01 ;{ }^{* * *} P<0.001\right.$ significantly different from control). (C) Representative confocal images of CD44 expression in control and treated tissues from NOD-SCID mice injected with 100 5FU-S and 250 5FU-R HCT116 G1 spheres. Images were analyzed and quantified by Carl Zeiss Zen 2012 image software. 
CSCs that is majorly responsible for tumor recurrence. This effect could be further enhanced with long-term exposure to TQ. Studies on the anticancer therapeutic potential of TQ and its safety profiles in humans are very limited and its pharmacologically relevant doses in animal or human blood have not been determined. In a Phase I clinical trial, TQ was found to be well tolerated at doses up to $10 \mathrm{mg} / \mathrm{kg} /$ day but no significant anticancer activity was observed at this dose [50]. A recent Phase II clinical study evaluating the effect of $100 \mathrm{mg}$ and $200 \mathrm{mg}$ TQ on oral potential malignant lesions is currently registered; however, it is still not open for participant recruitment (https:/clinicaltrials.gov/ct2/show/NCT03208790?term =thymoquinone\&rank=1). Nevertheless, several clinical trials testing the effect of Nigella sativa on various diseases including beta thalassemia major in children, dyslipidemia and arsenical keratosis have shown that it is not toxic in patients at doses up to $300 \mathrm{mg} / \mathrm{day}$. (https:// clinicaltrials.gov/ct $2 /$ results? cond $=\&$ term $=$ nigella + sativa \&type $=\& \mathrm{rslt}=$ \&age $\mathrm{v}=$ \& gndr $=$ \&intr $=$ \&titles $=\&$ outc $=\& \mathrm{~s}$ pons $=\&$ lead $=\& \mathrm{id}=\&$ cntry $=\&$ state $=\&$ city $=\&$ dist $=\&$ locn $=$ \&strd_s=\&strd_e=\&prcd_s=\&prcd_e=\&sfpd_s=\&sfpd $\mathrm{e}=$ \&lupd $\mathrm{s}=$ \&lupd $\mathrm{e}=\&$ sort $=$ ). The oral administration of TQ was found to be safe in several animal models [51]. The LD50 of TQ in mice and rats ranged between 57 and $104 \mathrm{mg} / \mathrm{kg}$ when injected intraperitoneally and reached $870 \mathrm{mg} / \mathrm{kg}$ when given orally (reviewed in Ref [52].), all of which are much higher doses than the effective anticancer dose of $20 \mathrm{mg} / \mathrm{kg}$ used in this study.

The macroscopically observed growth delay in HCT116 mouse xenografts was due to reduced proliferation of tumor cells and to drug-induced apoptosis as evidenced by decreased PCNA expression, upregulated p53 and p21 expression and enhanced TUNEL positivity in treated xenografts. To identify signaling pathways that might be involved in TQ's effect on colorectal CSCs, we examined NF- $\kappa \mathrm{B}(\mathrm{p} 65)$ and $\mathrm{MEK} / \mathrm{p}-\mathrm{MEK}$ expression. $\mathrm{NF}-\kappa \mathrm{B}$ is a crucial factor involved in the pathogenesis of inflammation mediated cancer through activation of genes and cytokines required for the induction of cellular proliferation [20] and has been shown to be regulated by TQ $[53,54]$. In addition, MAPK signaling pathway is dysregulated in colorectal cancer, and various approaches for blocking signaling through this pathway have been studied [55]. We have previously shown that the inhibition of ERK pathway by MEK inhibitor PD98059 potentiated apoptosis induction by TQ [26]. We also documented that TQ directly binds to PAK1/ERK kinase complex, induces considerable conformational changes of PAK1 and interrupts its function as a scaffold for ERK1/2/MEK to recruit MEK to RAF at the membrane [56]. Importantly, MEK kinase was shown to induce NF- $\kappa$ B activation through the degradation of I $\kappa \mathrm{B}-\alpha$, a major inhibitor of NF$\kappa \mathrm{B}$ [57]. Interestingly, TQ treatment reduced NF- $\kappa \mathrm{B}(\mathrm{p} 65)$ and $p-M E K$ and upregulated $\mathrm{I} \kappa \beta-\alpha$ expression in xenograft mouse tissues, suggesting a role for MEK as a signal mediator involved in $\mathrm{I} \kappa \beta-\alpha$-induced NF- $\kappa \mathrm{B}$ inhibition. Downregulation in NF- $\mathrm{B}$, p-MEK and PCNA was also observed in vitro especially in TQ-treated colonospheres highlighting the importance and advantage of 3D culture as a better mimic of in vivo environment.

Our study demonstrated that low concentrations of TQ could target CSCs enriched from 5FU-sensitive and resistant colorectal cancer HCT116 cell lines, suggesting a promising effect of TQ on chemoresistant cells. This effect when coupled with the apoptotic effects of TQ in human CRC cultures and xenografts indicates that this relatively non-toxic and inexpensive compound merits further clinical investigation.

\section{MATERIALS AND METHODS}

\section{Cell culture conditions}

Human colorectal cancer HCT116 5FU-sensitive (5FU-S) cells were purchased from ATCC and HCT116 5FU-resistant (5FU-R) cells were obtained from the group of Prof. Nadine Darwiche (American University of Beirut, Lebanon) [58]. Cells were cultured in their respective media either on Matrigel ${ }^{\mathrm{TM}}$ (BD Bioscience, Franklin Lakes, NJ, USA) or in 2D monolayer conditions. HCT116 cells were maintained in RPMI 1640 (SigmaAldrich, Germany) with $20 \mathrm{mM}$ HEPES and L-Glutamine supplemented with antibiotics $[1 \%$ PenicillinStreptomycin $(100 \mathrm{U} / \mathrm{ml})]$ and 10\% heat-inactivated fetal bovine serum (FBS) (Sigma-Aldrich, Germany). The cells were mycoplasma free and were maintained in an incubator at $37^{\circ} \mathrm{C}$ in a humidified atmosphere of $5 \% \mathrm{CO}_{2}$ and $95 \%$ air.

\section{Drug preparation and treatment}

Directly before use, fresh stocks of the purified synthetic compound TQ (Sigma-Aldrich: CAS: 490-91-5; 99.5\% purity) in methanol and of 5FU (Sigma-Aldrich, Germany) in dimethylsulfoxide (DMSO) were prepared. Intermediate concentrations of the drugs were then made by serial dilutions from stock every two days during sphere formation assay. We assessed the sphere formation unit variation in response to different treatment conditions.

\section{MTT cell viability assay}

5FU-sensitive and resistant HCT116 cells were plated in $100 \mu \mathrm{l}$ complete medium in 96-well culture plates at a density of 10,000 and 12,000 cells/well, respectively. Cells were incubated overnight then treated in triplicates with various drug concentrations for 24, 48, and $72 \mathrm{hrs}$. Each experiment was repeated three times and in triplicate measurements. Cell viability was then assessed by MTT [3-(4, 5-dimethylthiazol-2-yl)-2, 5-diphenyltetrazolium bromide] that measures the ability of metabolically active 
cells to convert tetrazolium salt into violet formazan crystals. At specific time points, MTT reagent was added to each well and incubated at $37^{\circ} \mathrm{C}$ for $4 \mathrm{hrs}$. $100 \mu \mathrm{l}$ isopropanol was used as a solubilizing solution to dissolve violet crystals. Consequently, MTT optical density (OD) was measured at a wavelength of $595 \mathrm{~nm}$ using ELISA reader (Multiskan Ex). Cell viability was expressed as a percentage of the control.

\section{Trypan blue viability assay}

Supernatants containing dead cells were collected, and attached live cells were harvested by trypsin EDTA and added to the supernatant. The cell pellet was resuspended in $100 \mu \mathrm{l}$ media, and $50 \mu \mathrm{l}$ of cell suspension was mixed with $50 \mu$ of trypan blue and then live/dead cells were counted using a hemocytometer.

\section{Transwell migration assay}

For the migration assay, $2.5 \times 10^{5} 5 \mathrm{FU}$-sensitive and $3.5 \times 10^{5} 5$ FU-resistant HCT116 cells were seeded in a serum-free medium with or without treatment in the top chamber of 24-well inserts (pore size, $8 \mathrm{~mm}$; Falcon), and a medium supplemented with serum was used as a chemo-attractant in the lower chamber. Cells were allowed to migrate through the membrane at $37^{\circ} \mathrm{C}$ in a $5 \% \mathrm{CO}_{2}$ incubator for 24 and $48 \mathrm{hrs}$. Non-migratory cells in the upper chamber were then gently scraped off with a cottontip applicator. Migrating cells on the lower surface of the membrane were fixed and stained with Hematoxylin and Eosin (H\&E). After staining, the total number of migrating cells was counted under the light microscope $(10 \times$ objective) from six consecutive fields for each well.

\section{Transwell invasion assay}

For the invasion assay, $2.5 \times 10^{5} 5 \mathrm{FU}$-sensitive and $3.5 \times 10^{5} 5 \mathrm{FU}$-resistant HCT116 cells were seeded in a serum-free medium with or without treatment in the top chamber onto the Matrigel ${ }^{\mathrm{TM}}$-coated membrane (24-well insert; pore size, $8 \mathrm{~mm}$; Falcon), and a medium supplemented with serum was used as a chemo-attractant in the lower chamber. Each well was freshly coated with $100 \mu \mathrm{l}$ of Matrigel $^{\mathrm{TM}}$ (BD Bioscience, Franklin Lakes, NJ, USA) at a dilution of 1:10 in cold PBS and was then airdried overnight before starting the invasion assay. Cells were allowed to migrate through the membrane coated with Matrigel ${ }^{\mathrm{TM}}$ at $37^{\circ} \mathrm{C}$ in a $5 \% \mathrm{CO}_{2}$ incubator for 24 and 48 hrs. Non-migratory cells in the upper chamber were then gently scraped off with a cotton-tip applicator. Invading cells on the lower surface of the membrane were fixed and stained with H\&E. After staining, the total number of invading cells was counted under the light microscope $(10 \times$ objective) from six consecutive fields for each well.

\section{Sphere formation assay}

HCT116 cells were able to generate spheres in nonadherent cultures. Single-cell suspension of HCT116 cell lines was counted, and a density of 2000 cells/well was suspended in cold Growth Factor Reduced Matrigel ${ }^{\mathrm{TM}}$ / serum-free RPMI-1640 medium (1:1) in a total volume of $50 \mu \mathrm{l}$ [59]. Each experimental condition was performed in duplicate. The master mix of cells with Matrigel ${ }^{\mathrm{TM}}$ was circularly plated at the rim of the well of a 24 -well plate and allowed to solidify in the incubator at $37^{\circ} \mathrm{C}$ for 45 minutes. Then $1 \mathrm{ml}$ media with 5\% FBS (with or without treatment) was added gently at the center of the well. Media or treatments were replenished every two days. Sphere counts and imaging were performed at day 9 and 13 of sphere culture, respectively, for the sensitive and resistant cell lines.

\section{Propagation assay}

To enrich for the stem-like population of cells, the media was aspirated from the well and the Matrigel ${ }^{\mathrm{TM}}$ -containing spheres were digested by $500 \mu \mathrm{l}$ dispase solution (Invitrogen, Carlsbad, CA, $1 \mathrm{mg}$ dissolved in $1 \mathrm{ml}$ RPMI-1640 incomplete medium) for $1 \mathrm{hr}$ at $37^{\circ} \mathrm{C}$. Spheres were collected and incubated in $0.5 \mathrm{ml}$ Trypsin/EDTA at $37^{\circ} \mathrm{C}$ for $1-3$ minutes. Single cells resulting from the dissociation of spheres were re-plated at the same density of 2000 cells/well in 24 -well plates.

\section{D imaging of colonospheres}

Spheres were grown then collected with cold RPMI media and centrifuged to washout all Matrigel debris. After centrifugation, spheres were fixed by formalin for 20 minutes. After washing with PBS three times, cells were permeabilized with $0.5 \%$ Triton $\mathrm{X}-100$ for 30 minutes and blocked with sphere blocking buffer $(0.1 \%$ BSA, $0.2 \%$ Triton X-100, 0.05\% Tween-20, and 10\% normal goat serum in PBS) for $2 \mathrm{hrs}$ at room temperature. Spheres were washed and incubated overnight at $4^{\circ} \mathrm{C}$ with primary antibodies with blocking solution. Spheres were then washed with PBS and incubated with secondary antibody (Alexa fluoro 488 and Alexa fluoro 568) for $1 \mathrm{hr}$ at room temperature. Finally, spheres were washed and mounted using the 5-7 $\mu \mathrm{L}$ anti-fade reagent Fluoro-gel II with DAPI (Abcam, Cambridge, UK). Fluorescent signals were captured using a Zeiss LSM 710 confocal microscope (Germany), and images were acquired and analyzed using the Zeiss LSM image software.

\section{TUNEL assay}

Apoptosis was determined using the In-Situ Cell Death Fluorescein Detection Kit (11684795910, SigmaAldrich, Germany). For visualization of nuclei and 
mounting Fluoroshield Mounting Medium with DAPI (ab104139; Abcam, Cambridge, UK) was used, and samples were analyzed by a confocal microscope (LSM 710; Zeiss Germany).

\section{Western blot analysis}

Spheres were grown with or without treatment then collected with cold RPMI media and centrifuged to wash out all Matrigel debris. Cells were plated in 100-mm tissue culture dishes and treated with 40 and $60 \mu \mathrm{M}$ TQ for 48 hrs. Cellular protein extracts were prepared in RIPA lysis buffer (sc-24948, Santa Cruz, CA, USA). Protein extracts were quantified using the DC Bio-Rad Protein Assay (BioRad Laboratories, Hercules, California, USA) according to the manufacturer's protocol. Protein samples were mixed with $10 \% \beta$-mercaptoethanol and $2 \times$ Laemmli Sample Buffer (Bio-Rad, CA, USA) for gel electrophoresis. An equal amount of protein lysate was separated on $12 \%$ SDS-PAGE for $2 \mathrm{hrs}$ at $90 \mathrm{~V}$ then transferred onto 0.45 $\mu \mathrm{m}$ nitrocellulose membrane (Bio-Rad, CA, USA) in transfer buffer overnight at $40^{\circ} \mathrm{C}$. Membranes were blocked with 5\% skim milk in tris-buffered saline with $0.1 \%$ tween 20 (TBST) for $1 \mathrm{hr}$ and then incubated overnight at $4^{\circ} \mathrm{C}$ with the primary antibody (all obtained from Santa Cruz, CA, USA; except GAPDH). Membranes were then washed three times with TBST and incubated with the diluted secondary antibody (Santa Cruz, CA, USA) for $1 \mathrm{hr}$ at room temperature. Hybridization with GAPDH-HRP (6C5) (1:10,000-20,000, Abnova, \#MAB5476) coupled antibody was performed for 30 minutes at room temperature as housekeeping gene. Target proteins were detected using the ECL system (Bio-Rad, CA, USA). Images were generated and quantified using ChemiDoc ${ }^{\mathrm{TM}}$ Imaging Systems (Bio-Rad, CA, USA).

\section{Histology and immunohistochemical analysis}

Serial tissue sections $(4 \mu \mathrm{m})$ were H\&E stained and analyzed by an expert who was blinded for the treatment groups. Immunohistochemical staining was performed on paraffin-embedded spheres and mouse tumor tissues using antibodies against the Epithelial Cell Adhesion Molecule (EpCAM) and Ki67 (Santa Cruz, CA, USA). Slides were dried, dewaxed in xylene and rehydrated using a decreasing alcohol series. After blocking of endogenous peroxidase with $\mathrm{H}_{2} \mathrm{O}_{2}$, antigen retrieval was performed in $10 \mathrm{mM}$ citrate buffer, $\mathrm{pH}$ 6. Subsequently, slides were blocked with Protein Block (Novolink Polymer Detection Kit, RE7150-K, Leica). Primary antibodies were incubated at $4^{\circ} \mathrm{C}$ overnight, followed by Post Primary and Novolink ${ }^{\mathrm{TM}}$ Polymer (Novolink Polymer Detection Kit, RE7150-K, Leica). Staining was visualized using 3,3-diaminobenzidine (DAB), and nuclear counterstaining was performed using hematoxylin (Novolink Polymer Detection Kit, RE7150-K, Leica Biosystems, Germany).
Slides were dehydrated and embedded in Histofluid (6900002; Marienfeld, Lauda Koenigshofen, Germany). Images were recorded at $40 \times$ to $400 \times$ magnification using an Olympus BH-2 microscope and an Olympus E330 digital camera. The staining intensity was classified into 0 (no staining), 1+ (weak), 2+ (moderate), 3+ (strong), and the average of positively stained cells was recorded.

\section{Animal experiments}

Six to eight week-old adult male NOD-SCID (injected with 5FU-sensitive cells) and NOG (injected with 5FU-resistant cells) mice were used. Mice were housed under optimum conditions of temperature set at $22 \pm 2{ }^{\circ} \mathrm{C}$ and light set at a $12 \mathrm{hrs}$ light-dark cycle. Mice were kept in plastic cages covered with sawdust and had unrestricted access to a commercial mouse $\operatorname{diet}(24 \%$ protein, $4.5 \%$ fat, $4 \%$ fiber) and water. All animal studies were conducted using a protocol approved by the Institutional Animal Care and Use Committee of the American University of Beirut.

For tumor induction in mice, cells or spheres were suspended in $50 \mu \mathrm{l}$ of the respective media, whereby cells or spheres were mixed with an equal volume of Matrigel. The mixture was subcutaneously injected into the flank of a group of mice. Animals were treated three times per week either with saline (control group) or TQ (20 mg/ $\mathrm{kg}$ ) by intraperitoneal injections when a palpable tumor was observed. Mice were daily monitored for signs of morbidity. Body weight recordings were carried out biweekly. Tumor volume was monitored every other day using Mitutoyo caliper.

\section{Statistical analysis}

All statistical analyses ( $t$-test and one-way ANOVA) were performed using GraphPad Prism 7 (version 7.0, GraphPad Software Inc., La Jolla, CA, USA). Normality of the data was confirmed using D'Agostino \& Pearson and Shapiro-Wilk normality tests. In all statistical tests, the mean of treated groups was compared to the mean of control groups and a $p$-value $<0.05$ was considered statistically significant.

\section{Author contributions}

F Ballout designed and performed the experiments with the help of A Monzer and M Fatfat. F Ballout and A Monzer acquired the data. F Ballout, W Abou Kheir and $\mathrm{H}$ Gali-Muhtasib analyzed and interpreted the data. MA Jaffa helped with the statistical analysis. R Abdel Samad and N Darwiche established and provided the 5FU-resistant HCT116 cell line. F Ballout wrote the study with comments from all the other authors. W Abou Kheir and H Gali-Muhtasib designed and supervised the study. All authors read and approved the final version of the manuscript. 


\section{ACKNOWLEDGMENTS}

The authors wish to thank the staff of the core facilities in the DTS Building at the American University of Beirut for their help and support.

\section{CONFLICTS OF INTEREST}

There are no conflicts of interest to declare.

\section{FUNDING}

This study was funded by the Medical Practice Plan (MPP 320129) and the University Research Board (URB 103007 and 103185) of the Faculty of Medicine at the American University of Beirut. The funding source had no involvement in study design; in the collection, analysis and interpretation of data; in the writing of the report or in the decision to submit the article for publication.

\section{REFERENCES}

1. American Cancer Society. Cancer Facts \& Figures 2018. Atlanta: American Cancer Society. 2018.

2. Arvelo F, Sojo F, Cotte C. Biology of colorectal cancer. Ecancermedicalscience. 2015; 9:520. https://doi. org/10.3332/ecancer.2015.520. [PubMed]

3. Pardini B, Kumar R, Naccarati A, Novotny J, Prasad RB, Forsti A, Hemminki K, Vodicka P, Lorenzo Bermejo J. 5-Fluorouracilbased chemotherapy for colorectal cancer and MTHFR/MTRR genotypes. Br J Clin Pharmacol. 2011; 72:162-3. https://doi. org/10.1111/j.1365-2125.2010.03892.x. [PubMed]

4. Phua LC, Mal M, Koh PK, Cheah PY, Chan EC, Ho HK. Investigating the role of nucleoside transporters in the resistance of colorectal cancer to 5-fluorouracil therapy. Cancer Chemother Pharmacol. 2013; 71:817-23. https:// doi.org/10.1007/s00280-012-2054-0. [PubMed]

5. He L, Zhu H, Zhou $\mathrm{S}, \mathrm{Wu} \mathrm{T}, \mathrm{Wu} \mathrm{H}$, Yang $\mathrm{H}$, Mao $\mathrm{H}$, SekharKathera C, Janardhan A, Edick AM, Zhang A, Hu Z, Pan F, et al. Wnt pathway is involved in 5-FU drug resistance of colorectal cancer cells. Exp Mol Med. 2018; 50:101. https://doi.org/10.1038/s12276-018-0128-8. [ [PubMed]

6. Riihimäki M, Hemminki A, Sundquist J, Hemminki K. Patterns of metastasis in colon and rectal cancer. Sci Rep. 2016; 6:29765. https://doi.org/10.1038/srep29765. [PubMed]

7. Munro MJ, Wickremesekera SK, Peng L, Tan ST, Itinteang T. Cancer stem cells in colorectal cancer: a review. J Clin Pathol. 2018; 71:110-116. https://doi.org/10.1136/ jclinpath-2017-204739. [PubMed]

8. Garza-Trevino EN, Said-Fernandez SL, MartinezRodriguez HG. Understanding the colon cancer stem cells and perspectives on treatment. Cancer Cell Int. 2015; 15:2. https://doi.org/10.1186/s12935-015-0163-7. [PubMed]

9. Xu ZY, Tang JN, Xie HX, Du YA, Huang L, Yu PF, Cheng XD. 5-Fluorouracil chemotherapy of gastric cancer generates residual cells with properties of cancer stem cells. Int J Biol Sci. 2015; 11:284-94. https://doi.org/10.7150/ ijbs.10248. [PubMed]

10. Takebe N, Harris PJ, Warren RQ, Ivy SP. Targeting cancer stem cells by inhibiting Wnt, Notch, and Hedgehog pathways. Nat Rev Clin Oncol. 2010; 8:97-106. https://doi. org/10.1038/nrclinonc.2010.196. [PubMed]

11. Paldino E, Tesori V, Casalbore P, Gasbarrini A, Puglisi MA. Tumor initiating cells and chemoresistance: which is the best strategy to target colon cancer stem cells? Biomed Res Int. 2014; 2014:859871. https://doi. org/10.1155/2014/859871. [PubMed]

12. Shanmugam MK, Arfuso F, Kumar AP, Wang L, Goh BC, Ahn KS, Bishayee A, Sethi G. Modulation of diverse oncogenic transcription factors by thymoquinone, an essential oil compound isolated from the seeds of Nigella sativa Linn. Pharmacol Res. 2018; 129:357-64. https://doi. org/10.1016/i.phrs.2017.11.023. [PubMed]

13. Schneider-Stock R, Fakhoury IH, Zaki AM, El-Baba CO, Gali-Muhtasib HU. Thymoquinone: fifty years of success in the battle against cancer models. Drug Discov Today. 2014; 19:18-30. https://doi.org/10.1016/i.drudis.2013.08.021. [PubMed]

14. Mollazadeh H, Afshari AR, Hosseinzadeh H. Review on the Potential Therapeutic Roles of Nigella sativa in the Treatment of Patients with Cancer: Involvement of Apoptosis: - Black cumin and cancer. J Pharmacopuncture. 2017; 20:158-72. https://doi.org/10.3831/kpi.2017.20.019. [ubMed]

15. Tavakkoli A, Mahdian V, Razavi BM, Hosseinzadeh H. Review on Clinical Trials of Black Seed (Nigella sativa) and Its Active Constituent, Thymoquinone. J Pharmacopuncture. 2017; 20:179-93. https://doi.org/10.3831/kpi.2017.20.021. [PubMed]

16. Woo CC, Hsu A, Kumar AP, Sethi G, Tan KHB. Thymoquinone inhibits tumor growth and induces apoptosis in a breast cancer xenograft mouse model: the role of $\mathrm{p} 38$ MAPK and ROS. PLoS One. 2013; 8:e75356. https://doi. org/10.1371/journal.pone.0075356. [PubMed]

17. Khalife R, Hodroj MH, Fakhoury R, Rizk S. Thymoquinone from Nigella sativa Seeds Promotes the Antitumor Activity of Noncytotoxic Doses of Topotecan in Human Colorectal Cancer Cells in Vitro. Planta Med. 2016; 82:312-21. https:// doi.org/10.1055/s-0035-1558289. [PubMed]

18. Zhu WQ, Wang J, Guo XF, Liu Z, Dong WG. Thymoquinone inhibits proliferation in gastric cancer via the STAT3 pathway in vivo and in vitro. World J Gastroenterol. 2016; 22:4149-59. https://doi.org/10.3748/ wig.v22.i16.4149. [PubMed]

19. Lang M, Borgmann M, Oberhuber G, Evstatiev R, Jimenez K, Dammann KW, Jambrich M, Khare V, Campregher C, Ristl R, Gasche C. Thymoquinone attenuates tumor growth in ApcMin mice by interference with Wnt-signaling. Mol Cancer. 2013; 12:41. https://doi.org/10.1186/1476-4598-12-41. [PubMed]

20. Mahmoud YK, Abdelrazek HMA. Cancer: Thymoquinone antioxidant/pro-oxidant effect as potential anticancer 
remedy. Biomed Pharmacother. 2019; 115:108783. https:// doi.org/10.1016/j.biopha.2019.108783. [PubMed]

21. Ndreshkjana B, Capci A, Klein V, Chanvorachote P, Muenzner JK, Huebner K, Steinmann S, ErlenbachWuensch K, Geppert CI, Agaimy A, Ballout F, El-Baba C, Gali-Muhtasib H, et al. Combination of 5-fluorouracil and thymoquinone targets stem cell gene signature in colorectal cancer cells. Cell Death Dis. 2019; 10:379. https://doi. org/10.1038/s41419-019-1611-4. [ubMed]

22. Ballout F, Habli Z, Rahal ON, Fatfat M, Gali-Muhtasib H. Thymoquinone-based nanotechnology for cancer therapy: promises and challenges. Drug Discov Today. 2018; 23:1089-98. https://doi.org/10.1016/j.drudis.2018.01.043. [PubMed]

23. Nagi MN, Mansour MA. Protective effect of thymoquinone against doxorubicin-induced cardiotoxicity in rats: a possible mechanism of protection. Pharmacol Res. 2000; 41:283-9. https://doi.org/10.1006/phrs.1999.0585. [PubMed]

24. Pathan SA, Jain GK, Zaidi SM, Akhter S, Vohora D, Chander P, Kole PL, Ahmad FJ, Khar RK. Stabilityindicating ultra-performance liquid chromatography method for the estimation of thymoquinone and its application in biopharmaceutical studies. Biomed Chromatogr. 2011; 25:613-20. https://doi.org/10.1002/bmc.1492. [PubMed]

25. Alkharfy KM, Ahmad A, Khan RM, Al-Shagha WM. Pharmacokinetic plasma behaviors of intravenous and oral bioavailability of thymoquinone in a rabbit model. Eur $\mathrm{J}$ Drug Metab Pharmacokinet. 2015; 40:319-23. https://doi. org/10.1007/s13318-014-0207-8. [PubMed]

26. El-Najjar N, Chatila M, Moukadem H, Vuorela H, Ocker M, Gandesiri M, Schneider-Stock R, Gali-Muhtasib H. Reactive oxygen species mediate thymoquinone-induced apoptosis and activate ERK and JNK signaling. Apoptosis. 2010; 15:183-95. https://doi.org/10.1007/s10495-0090421-z. [PubMed]

27. Gali-Muhtasib H, Ocker M, Kuester D, Krueger S, ElHajj Z, Diestel A, Evert M, El-Najjar N, Peters B, Jurjus A, Roessner A, Schneider-Stock R. Thymoquinone reduces mouse colon tumor cell invasion and inhibits tumor growth in murine colon cancer models. J Cell Mol Med. 2008; 12:330-42. https://doi.org/10.1111/j.15824934.2007.00095.x. [PubMed]

28. Todaro M, Francipane MG, Medema JP, Stassi G. Colon cancer stem cells: promise of targeted therapy. Gastroenterology. 2010; 138:2151-62. https://doi. org/10.1053/j.gastro.2009.12.063. [PubMed]

29. Hammond WA, Swaika A, Mody K. Pharmacologic resistance in colorectal cancer: a review. Ther Adv Med Oncol. 2016; 8:5784. https://doi.org/10.1177/1758834015614530. [PubMed]

30. Denise C, Paoli P, Calvani M, Taddei ML, Giannoni E, Kopetz S, Kazmi SM, Pia MM, Pettazzoni P, Sacco E, Caselli A, Vanoni M, Landriscina M, et al. 5-fluorouracil resistant colon cancer cells are addicted to OXPHOS to survive and enhance stem-like traits. Oncotarget. 2015;
6:41706-21. $\quad$ https://doi.org/10.18632/oncotarget.5991. [PubMed]

31. Lei X, Lv X, Liu M, Yang Z, Ji M, Guo X, Dong W. Thymoquinone inhibits growth and augments 5-fluorouracil-induced apoptosis in gastric cancer cells both in vitro and in vivo. Biochem Biophys Res Commun. 2012; 417:864-8. $\quad$ https://doi.org/10.1016/j.bbrc.2011.12.063. [PubMed]

32. Kensara OA, El-Shemi AG, Mohamed AM, Refaat B, Idris $\mathrm{S}$, Ahmad J. Thymoquinone subdues tumor growth and potentiates the chemopreventive effect of 5-fluorouracil on the early stages of colorectal carcinogenesis in rats. Drug Des Devel Ther. 2016; 10:2239-53. https://doi.org/10.2147/ DDDT.S109721. [PubMed]

33. Du L, Wang H, He L, Zhang J, Ni B, Wang X, Jin H, Cahuzac N, Mehrpour M, Lu Y, Chen Q. CD44 is of Functional Importance for Colorectal Cancer Stem Cells. Clin Cancer Res. 2008; 14:6751-60. https://doi. org/10.1158/1078-0432.CCR-08-1034. [PubMed]

34. Kemper K, Grandela C, Medema JP. Molecular identification and targeting of colorectal cancer stem cells. Oncotarget. 2010; 1:387-95. https://doi.org/10.18632/ oncotarget.173. [PubMed]

35. Gali-Muhtasib H, Kuester D, Mawrin C, Bajbouj K, Diestel A, Ocker M, Habold C, Foltzer-Jourdainne C, Schoenfeld P, Peters B, Diab-Assaf M, Pommrich U, Itani W, et al. Thymoquinone triggers inactivation of the stress response pathway sensor CHEK1 and contributes to apoptosis in colorectal cancer cells. Cancer Res. 2008; 68:5609-18. https://doi.org/10.1158/0008-5472.Can-08-0884. [PubMed]

36. Mirza-Aghazadeh-Attari M, Darband SG, Kaviani M, Mihanfar A, Aghazadeh Attari J, Yousefi B, Majidinia M. DNA damage response and repair in colorectal cancer: Defects, regulation and therapeutic implications. DNA Repair. 2018; 69:34-52. https://doi.org/10.1016/j. dnarep.2018.07.005. [PubMed]

37. Bressy C, Majhen D, Raddi N, Jdey W, Cornilleau G, Zig L, Guirouilh-Barbat J, Lopez BS, Bawa O, Opolon P, Grellier $\mathrm{E}$, Benihoud K. Combined therapy of colon carcinomas with an oncolytic adenovirus and valproic acid. Oncotarget. 2017; 8:97344-60. https://doi.org/10.18632/oncotarget.22107. [PubMed]

38. Kim YB, Jeung HC, Jeong I, Lee K, Rha SY, Chung HC, Kim GE. Mechanism of enhancement of radiation-induced cytotoxicity by sorafenib in colorectal cancer. J Radiat Res. 2013; 54:52-60. https://doi.org/10.1093/jrr/rrs074. [PubMed]

39. Fragkos M, Jurvansuu J, Beard P. H2AX is required for cell cycle arrest via the p53/p21 pathway. Mol Cell Biol. 2009; 29:2828-40. https://doi.org/10.1128/mcb.01830-08. [PubMed]

40. Chiu SJ, Lee YJ, Hsu TS, Chen WS. Oxaliplatin-induced gamma-H2AX activation via both p53-dependent and -independent pathways but is not associated with cell cycle arrest in human colorectal cancer cells. Chem Biol 
Interact. 2009; 182:173-82. https://doi.org/10.1016/j. cbi.2009.08.019. [PubMed]

41. Verma R, Rigatti MJ, Belinsky GS, Godman CA, Giardina C. DNA damage response to the Mdm2 inhibitor nutlin-3. Biochem Pharmacol. 2010; 79:565-74. https://doi. org/10.1016/j.bcp.2009.09.020. [PubMed]

42. Wang T, Han P, He Y, Zhao C, Wang G, Yang W, Shan M, Zhu Y, Yang C, Weng M, Wu D, Gao L, Jin X, et al. Lin28A enhances chemosensitivity of colon cancer cells to 5-FU by promoting apoptosis in a let-7 independent manner. Tumour Biol. 2016; 37:7657-65. https://doi.org/10.1007/s13277015-4559-8. [PubMed]

43. El-Merahbi R, Liu YN, Eid A, Daoud G, Hosry L, Monzer A, Mouhieddine TH, Hamade A, Najjar F, Abou-Kheir W. Berberis libanotica Ehrenb extract shows anti-neoplastic effects on prostate cancer stem/progenitor cells. PLoS One. 2014; 9:e112453. https://doi.org/10.1371/journal. pone.0112453. [PubMed]

44. Khan MA, Tania M, Wei C, Mei Z, Fu S, Cheng J, Xu $\mathrm{J}, \mathrm{Fu}$ J. Thymoquinone inhibits cancer metastasis by downregulating TWIST1 expression to reduce epithelial to mesenchymal transition. Oncotarget. 2015; 6:19580-91. https://doi.org/10.18632/oncotarget.3973. [PubMed]

45. Li J, Khan MA, Wei C, Cheng J, Chen H, Yang L, Ijaz I, $\mathrm{Fu}$ J. Thymoquinone Inhibits the Migration and Invasive Characteristics of Cervical Cancer Cells $\mathrm{SiHa}$ and CaSki In Vitro by Targeting Epithelial to Mesenchymal Transition Associated Transcription Factors Twist1 and Zeb1. Molecules. 2017; 22:2105. https://doi.org/10.3390/ molecules22122105. [PubMed]

46. Hsu HH, Chen MC, Day CH, Lin YM, Li SY, Tu CC, Padma VV, Shih HN, Kuo WW, Huang CY. Thymoquinone suppresses migration of LoVo human colon cancer cells by reducing prostaglandin E2 induced COX-2 activation. World J Gastroenterol. 2017; 23:1171-9. https://doi. org/10.3748/wig.v23.i7.1171. [PubMed]

47. Holle AW, Kalafat M, Ramos AS, Seufferlein T, Kemkemer R, Spatz JP. Intermediate filament reorganization dynamically influences cancer cell alignment and migration. Sci Rep. 2017; 7:45152. https://doi.org/10.1038/srep45152. [PubMed]

48. Majumdar D, Tiernan JP, Lobo AJ, Evans CA, Corfe BM. Keratins in colorectal epithelial function and disease. Int J Exp Pathol. 2012; 93:305-18. https://doi.org/10.1111/ j.1365-2613.2012.00830.x. [PubMed]

49. Pastuszak M, Groszewski K, Pastuszak M, Dyrla P, Wojtun $\mathrm{S}$, Gil J. Cytokeratins in gastroenterology. Systematic review. Prz Gastroenterol. 2015; 10:61-70. https://doi. org/10.5114/pg.2015.51182. [PubMed]
50. Al-Amri A, Bamosa A. Phase I safety and clinical activity study of thymoquinone in patients with advanced refractory malignant disease. Shiraz E-Med J. 2009; 10:107-11.

51. Abukhader MM. The effect of route of administration in thymoquinone toxicity in male and female rats. Indian $\mathrm{J}$ Pharm Sci. 2012; 74:195-200. https://doi.org/10.4103/0250474x.106060. [PubMed]

52. Asaduzzaman Khan M, Tania M, Fu S, Fu J. Thymoquinone, as an anticancer molecule: from basic research to clinical investigation. Oncotarget. 2017; 8:51907-19. https://doi. org/10.18632/oncotarget.17206. [PubMed]

53. Siveen KS, Mustafa N, Li F, Kannaiyan R, Ahn KS, Kumar AP, Chng WJ, Sethi G. Thymoquinone overcomes chemoresistance and enhances the anticancer effects of bortezomib through abrogation of NF- $\kappa \mathrm{B}$ regulated gene products in multiple myeloma xenograft mouse model. Oncotarget. 2014; 5:634-48. https://doi.org/10.18632/ oncotarget.1596. [PubMed]

54. Chen MC, Lee NH, Hsu HH, Ho TJ, Tu CC, Chen RJ, Lin YM, Viswanadha VP, Kuo WW, Huang CY. Inhibition of $\mathrm{NF}-\kappa \mathrm{B}$ and metastasis in irinotecan (CPT-11)-resistant LoVo colon cancer cells by thymoquinone via JNK and p38. Environ Toxicol. 2017; 32:669-78. https://doi.org/10.1002/ tox.22268. [PubMed]

55. Lin L, Ding D, Jiang Y, Li Y, Li S. MEK inhibitors induce apoptosis via FoxO3a-dependent PUMA induction in colorectal cancer cells. Oncogenesis. 2018; 7:67. https:// doi.org/10.1038/s41389-018-0078-y. [PubMed]

56. El-Baba C, Mahadevan V, Fahlbusch FB, Mohan SS, Rau TT, Gali-Muhtasib H, Schneider-Stock R. Thymoquinoneinduced conformational changes of PAK1 interrupt prosurvival MEK-ERK signaling in colorectal cancer. Mol Cancer. 2014; 13:201. https://doi.org/10.1186/1476-459813-201. [PubMed]

57. Kloster MM, Naderi EH, Carlsen H, Blomhoff HK, Naderi $\mathrm{S}$. Hyperactivation of NF- $\mathrm{B}$ via the MEK signaling is indispensable for the inhibitory effect of cAMP on DNA damage-induced cell death. Mol Cancer. 2011; 10:45. https://doi.org/10.1186/1476-4598-10-45. [PubMed]

58. Abdel-Samad R, Aouad P, Gali-Muhtasib H, Sweidan Z, Hmadi R, Kadara H, D'Andrea EL, Fucci A, Pisano C, Darwiche N. Mechanism of action of the atypical retinoid ST1926 in colorectal cancer: DNA damage and DNA polymerase $\alpha$. Am J Cancer Res. 2018; 8:39-55. [PubMed]

59. Abou-Kheir WG, Hynes PG, Martin PL, Pierce R, Kelly K. Characterizing the Contribution of Stem/Progenitor Cells to Tumorigenesis in the Pten-/-TP53-/- Prostate Cancer Model. Stem Cells. 2010; 28:2129-40. https://doi. org $/ 10.1002 /$ stem.538. [PubMed] 